\title{
Social Sustainable Accessibility for Disabled Person through Sustainable Development Goals in Malaysia
}

\section{Halmi Zainol'1, Haryati Mohd Isa², Siti Rashidah Md Sakip³, Ainaa Azmi ${ }^{4}$}

\author{
1, 2, 3 Faculty of Architecture, Planning and Surveying, \\ ${ }^{4}$ Center of Post Graduate Studies, \\ Universiti Teknologi MARA, Perak Branch, 32610 Seri Iskandar, Perak, Malaysia \\ halmi461@perak.uitm.edu.my, harya996@perak.uitm.edu.my, \\ sitir704@perak.uitm.edu.my, ainaaazmi1994@gmail.com \\ Tel: +60195582282
}

\begin{abstract}
The sustainable design for accessibility is essential in all aspects of physical development. The accessibility of social sustainable for people with disabilities (PWDs) is essential to ensure that they do not feel segregated from the community. The facilities provided must be user-friendly at places where they live and work. Although there are common facilities for PWDs, most of them do not function well and are not convenient to be used by the disabled people. One primary way to assist them to be self-dependent and self-reliant is to improve the accessibility for people with disabilities at public transport stations.

Keywords: Social; Sustainable; Disabled; PWDs

eISSN 2398-4279 @ 2019. The Authors. Published for AMER ABRA cE-Bs by e-International Publishing House, Ltd., UK. This is an open access article under the CC BY-NC-ND license (http://creativecommons.org/licenses/bync-nd/4.0/). Peer-review under responsibility of AMER (Association of Malaysian Environment-Behaviour Researchers), ABRA (Association of Behavioural Researchers on Asians) and CE-Bs (Centre for EnvironmentBehaviour Studies), Faculty of Architecture, Planning \& Surveying, Universiti Teknologi MARA, Malaysia.

DOI: https://doi.org/10.21834/ajqol.v4i16.195
\end{abstract}




\subsection{Introduction}

Accessibility is one of the important keys in our daily routine particularly in connecting with the environment whether internally or externally. However, most of the public transport stations have serious problems in term of having good designs and facilities. These issues of poor accessibility at public stations have become a burden that prevents many disabled people from using them as a connection to other places (Soltani, Sham, Awang \& Yaman, 2012). In order to develop our cities to become "world class", sustainable design for accessibility must be accounted for in all physical developments. Accessibility in the built environment is progressively applicable in Malaysia, not only to prepare for the ageing population and disabled people but also for the whole of Malaysia's population (Rahim, Zen, Samad \& Rahim, 2014).

In due course to resolve the accessibility issues, the Sustainable Development Goals (SDGs) were created as a universal call to end poverty, protect the planet and ensure all communities can enjoy the peace and have sustainable well-being. There are 17 Goals in the SDGs, namely no poverty, zero hunger, good health and well-being, quality education, gender equality, clean water and sanitation, affordable and clean energy, decent work and economic growth, industry, innovation and infrastructure. Besides, to reduce inequalities, sustainable cities and communities, responsible consumption and production, climate action, life below water, life on land, peace, justice and strong institutions and partnerships for the goals. The SDGs act as a spirit to make the right decision to increase life quality and make it sustainable for future generations. The goals were guided to adopt better environmental life, not only for Malaysia but other countries too (UNDP, 2018).

Correspondingly, other than the SDGs, there are other Malaysia plans dealing with the accessibility issues for PWDs such as `Pelan Tindakan Orang Kurang Upaya (OKU) 20162022 ' by The Ministry of Women, Family and Community Development. They highlighted ten strategic thrusts. Strategic thrust no 1 (ST1) is to increase the accessibility and usability of PWDs on public transportation. They shall have the same rights to access and use public facilities, amenities, services and buildings. As in Malaysia, it is mandatory for all public buildings to provide access and facilities for PWDs according to the Malaysia Standard (MS) and the first legally binding disabled people's right (Islam, 2015). However, Malaysia is still very much lacking in considering equal accessibilities and facilities for this group of people.

PWDs can have a higher degree sense of independence when they can participate in normal activities. One example is when they can use public facilities such as public transport without having any obstacles. Social participation such as ridesharing should be extended to the disabled people as well. Having a commendable social network in the community will integrate a healthier and better quality of community life. According to Bascom (2017), the increased number of disabled people in social networks may give a negative impact on their social life. The existence of social interaction with the PWDs is an opportunity for social sustainability and life-enhancing conditions in the community. Thus, developing and building proper access for PWDs in public areas are primary ways to help them to be independent and self-determined (Bascom, 2017). Based on these issues, the focus of the study is to identify the accessibility of social sustainability for the PWDs in public transport stations in Malaysia. The primary aim of the paper is to identify the relationship between Sustainable 
Development Goals (SDGs) and social sustainability among the PWDs in accessing the facilities provided at public transport stations in Malaysia.

\subsection{Literature Review}

The rise of sustainability is significant after the Brundtland Report (1987) on Our Common Future used. It defined sustainable as the development that meets the needs of the present without compromising the ability of future generations to meet their own needs. Social sustainability is the pillar of sustainable development. Other elements that contribute to sustainability are the economy and the environment. As mentioned by Sierra, Yepes and Pelicer (2018), one of the essential aspects of social sustainability is to improve the quality of life for all people in the living environment.

\subsection{Urban Well-being and Sustainable Development}

Today, the number of people staying in urban areas exceeds the number of those staying in rural areas. During the period encompassed by SDGs, the pace and scale of urban development will continue (Siri \& Capon, 2015). About 6.5 billion people are estimated to need houses in the urban areas by the year 2050. However, sustainable development is unachievable without outstandingly transforming the way urban spaces are being created and ruled. Therefore, in 2015 in order to handle issues in communities in the urban areas, SDGs highlighted Goal 11 which is 'Sustainable Cities and Communities'. Extreme poverty is often found in urban areas if compared to the rural areas. Creating cities that are safe and sustainable means to provide safe accessibility, affordable housing and also to upgrade slum settlements. These actions do not only involve investment in the public transport system to create green public spaces, but also involve upgrading urban planning and management without any exception (UNDP, 2018). Figure 1 shows the accessibility of facilities that can help to improve PWDs' well-being

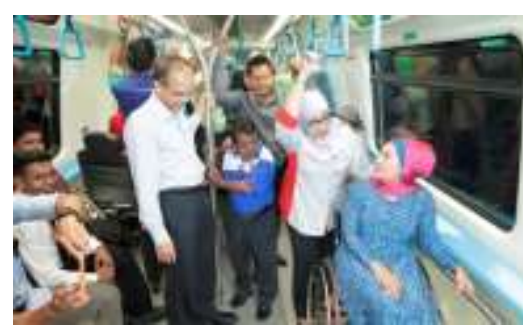

(a)

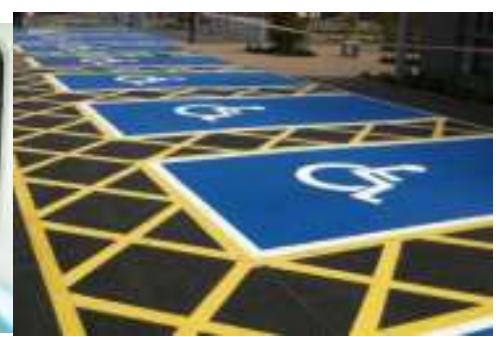

(b)

Fig 1. (a) Facilities in train (b) Parking space for disabled (Sources: Ishak, 2017)

The ways of urban settlements are planned, designed, develop and managed to affect human health, wellbeing, safety, security and opportunity. It is vital to make cities more sustainable from economic or environmental perspectives without ignoring the security of 
human health and wellbeing. Moreover, public transport such as bus and train are sustainable urban transport that can reduce the gas emissions. However, it is not focusing on human health and wellbeing that makes opportunity for using public transport fail (Siri \& Capon, 2015). Additionally, development must fulfil the needs of the present without weakening the capability of future generations to achieve their own needs. Economy, environmental and society were three components of sustainable development (Mokthsim \& Salleh, 2014). The first generation of sustainable design was on energy efficiency, alternative building materials, conservation, and recycling. While, the second generation of sustainable design was more on the integration of all the factors that can produce the best results which involve meeting the needs of society for the present as well as future needs (Rahim et al., 2014).

\subsection{Social Sustainability}

The word 'social' was integrated late into debates on developing sustainability (Eizenberg \& Jabareen, 2017). The primary challenges in our society are the mounting levels of evolving risk, vulnerability resulting from social polarisation, rising urban poverty levels, urban conflict and violence, terrorism, natural disaster and climate change (Jabareen, 2015). Social life can be either inclusive or exclusive, but when it comes to PWDs, most of it is social exclusion. It is a "multidimensional phenomenon" related to a person, social, economy, socio-economic, organisation, politics and other institutions. This phenomenon makes disabled people not capable of participating in the community because of a particular issue (Islam, 2015). Therefore, social sustainability is essential to make sure that PWDs are not excluded from society but can enjoy the same facilities and freedom in life.

Based on previous research, the definition of social sustainability varies. According to Eizenberg and Jabareen (2017), social sustainability refers to places where people want to live and work, now and in the future. They meet the diverse needs of existing and future residents, are sensitive to their environment, and contribute to a high quality of life. They are safe and inclusive, well planned, built and run, and offer equality of opportunity and excellent services for all. All types of people in the community including PWDs deserve to enjoy and live with quality facilities that are user-friendly. The integration among the communities in the neighbourhood also plays an essential role in treating PWDs as ordinary people. The close relationship resulted from this integration is the key to a healthy living environment (Dempsey, Brown \& Bramley, 2012).

One important key to achieving social sustainability is to tackle the problems that are currently faced by those who live in urban communities. Sustainability is obtainable if the social processes and structures provided are acknowledged to meet the needs of the community which are ever-changing from time to time (Vallance, Perkins \& Dixon, 2011). According to Jabareen (2015), social sustainability comes with urban planning and design principles, such as compactness, mixed-used, density, sustainable transport, and greening.

PWDs have been mistreated, harassed and discriminated at work even though they are more committed and well-performed than ordinary people (Soltani et al., 2012). They usually conceal their disabilities with a display of competency at work (Kaur et al. 2015). However, the public has low acceptance towards them (PWDs). They are teased, hated, negatively 
viewed and overly-sympathised. Their disabilities make them become more excluded from the community. As a result, they are vulnerably exposed to the risk of social exclusion (Islam, 2015).

\subsection{Methodology}

This section explains the research method used in this paper. The paper focused on social sustainability for PWDs. The methodology used for this paper is divided into two parts. The first part of the review focuses on social sustainability. Relevant references were gathered such as the definition, social sustainability and attributes that contribute to the quality of life. Issues on social sustainability for PWDs were also discussed. It was found that social sustainability supports the ability of future nations to maintain a healthy community by engaging PWDs.

The second part of the literature review is on sustainable development goals (SDGs) The review of this area was gathered from previous studies through electronic journals, books, research papers and websites. Sustainable development goals which consist of 17 goals altogether help to revitalise sustainable development in the nation. Among the goals are to ensure healthy lives and promote well-being for all ages. Articles by various authors that are related to social sustainability were also reviewed. From the reviews on social sustainability and sustainable development, it was gathered that multiple aspects should be highlighted to bring PWDs into the community.

\subsection{Results}

A few findings were gathered from previous studies on social sustainability for PWDs. The engagement of public services in providing facilities for PWDs must be highlighted. Their existence must be taken into consideration in any planning for development. The development of any public transport buildings must include access and facilities for PWDs so that they can engage themselves with the community.

\subsection{Issues of Accessing for Disabled People}

It is estimated about $15 \%$ or equal to 1 billion of the world's population live with some disabilities (WHO Report, 2018). In Malaysia, there are about 365677 people with disability. The statistics on the types of disabilities is as shown Table 1

Based on Table 1, the top two highest types of disabilities in Malaysia are learning, and physical disabilities and the lowest is speech disability. Other disabilities such as visually impaired, hearing impaired, mentally impaired and others have a moderate population. However, in term of the connection with the accessibility of social facilities, this gives a significant impact on PWDs. The Persons with Disabilities Act 2008 (Act 685) (Law of Malaysia, 2007), defines PWDs as persons with long-term physical, mental, intellectual or sensory impairments in interaction with various obstacles that hindered them fully participation in the community or public (Kaur, Leong, Yusof \& Singh, 2015; Ismail, Marzuki, Daud \& Borham, 2015). The design of buildings is essential to make sure that everybody 
including PWDs can access and use the facilities. Also, PWDs and older adults stated that standing for an extended period was uncomfortable for them and sometimes not even possible (Soltani et al., 2012). However, most of the facilities provided at public transport stations pose severe problems and are unfriendly. The issues are due to the position, inclination and design. For example, the absence of walkways, platforms and wheelchair areas (Soltani et al., 2012; Ismail et al., 2015).

\section{Table 1. Statistics of Disabled People in Malaysia}

\begin{tabular}{lc}
\hline Type of disability & Percentage (\%) \\
\hline Learning disability & 35 \\
Physical & 34 \\
Visually impaired & 9 \\
Hearing impaired & 8 \\
Mentally disabled & 8 \\
Speech disabled & 1 \\
Others & 5 \\
\hline
\end{tabular}

Source: Department of Social Welfare, 2015

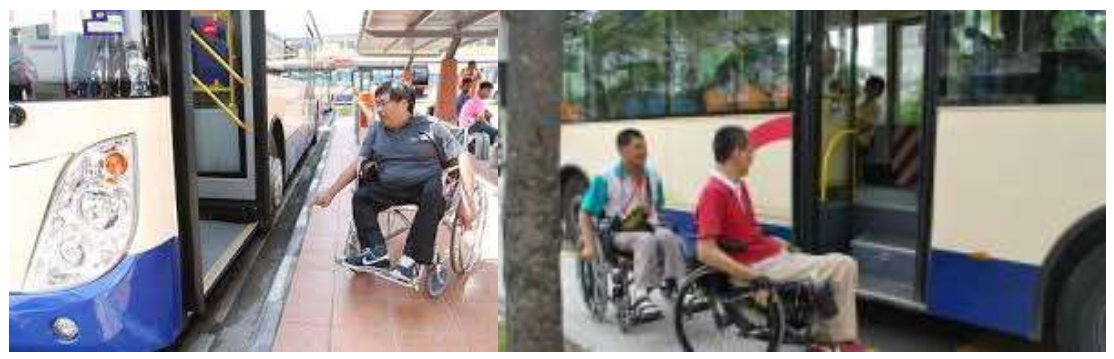

(a)

(b)

Fig. 2. (a) Difficult access onto the bus (b) Stairs and no ramp to get onto the bus (Sources: Yue, 2019 and Tan, 2008

PWDs are now qualified to exercise their civil, political, social, economic and cultural rights equally with others. At the Biwako Millennium Framework for Action and the Biwako Plus Five 2008 Convention, about 400 million PWDs claimed their rights and enjoyed equal opportunities concerning development and participation in society. As stated in the Federal Constitution and various acts in Malaysia, freedom of human rights is one of them. Without the right of mobility, it means the right to use public facilities could be less. To move freely in the education area, working place and other places, they need to use various types of public 
transport. However, in reality, PWDs lack or have limited access to social environment and employment, goods and services, thus resulting in stigmatisation and lack of training (Islam, 2015). The lack of accessibility to buildings is, depriving them of their right to education, employment, public transport, public facilities, business premises and social or religious place (Rahim et al., 2014).

Figures 2 (a) and 2 (b) show one of the problems faced by PWDs when using one type of public transport, the bus. They do not have access to board the bus. Kuala Lumpur Central Station and Klang Central Station were rated the lowest in providing friendly facilities for the disabled (Ishak \& MadSah, 2016). The same scenario can be seen in other countries as well. For example, at the Stratford and London Bridge bus station, the position, inclination, and availability of ramps pose serious problems. Meanwhile, the scenario at the London Bridge train station is more unfavourable because architectural barriers such as gaps, steep inclines or curbs, and wheelchair areas do not exist (Parker, May, Mitchell \& Burrows, 2013). Similarly, in Bangkok, the unavailability and lack of quality access facilities have made the older adults, and PWDs feel dissatisfied and unfairly treated. For example, at the Mo Chit Skytrain and Saphan Taksin Skytrain stations, the authority has failed to provide appropriate access facilities and elevators to accommodate the needs of the PWDs (Prasertsubpakij \& Nitivattananon, 2012).

\subsection{Comparison with Contribution to Urban Well-being and Sustainable Development}

The exclusion of PWDs at the community and social levels is due to the lack of interaction and involvement in activities with neighbours, friends, and society. Other causes of exclusion are inadequate access to public facilities such as transportation, sports and recreation. However, by improving the public transport facilities, they can easily have access to urban areas just like other ordinary people. Urban well-being is not only for ordinary people but also for PWDs. They can improve themselves financially by working which means that they need transportation to the workplace because not all of them can afford to buy a car. Besides, to find a parking space is never easy. Taking public transport is the best alternative for them to move around. It is also sustainable because people can connect to society and live the way they love now and in the future.

The use of high technology effectively in networking does not only create well-managed cities, but also it enables greater equity and inclusion, upgrades societal well-being and improves economic growth at lower rates of resource use, greenhouse gas emissions, and social costs. Based on UNDP (2018), the SDGs Goal 11 contributes to public well-being and sustainable development regarding increased inclusion and sustainable social capacity for participation. Besides, it also unites sustainable human settlement in planning and management all over the world. The SDGs Goal 11 helps to lower the percentage of deaths and the number of people who are affected by direct economic losses caused by global disasters. One example of a global catastrophe is a water-related disaster. SDGs Goal 11 focuses on protecting the poor people in vulnerable situations. As such, support from different communities from urban, semi-urban and rural areas is vital to creating a healthy society, a positive environment and strong well-being nation.

Social sustainability affiliates directly with physical factors. By providing the necessary 
facilities for all types of people, it not only provides attractive public realms but also improves the local environmental quality and convenience. Among the elements that influence the physical factors of social sustainability are accessibility, pedestrian-friendly, social interaction, physical activity, safety, health and sense of belonging (Eizenberg \& Jabareen, 2017 and Solvoll \& Hansen, 2017). However, these contributing factors have not been quantified as the factors that influence social sustainability in the public transport system.

\subsection{Findings}

The implementation of SDGs Goal 11 (Sustainable Cities and Communities) and improvement in social sustainability for PWDs can help in the economic growth. All PWDs can have a good connection with the community, thus helps to create job opportunities for them. If all of the facilities provided are user-friendly for them, they will get many benefits such as having equitable access to land, water, financial resources and technologies. Besides, various industry sectors will improve economically with the inclusion of PWDs in the community.

According to UNDP (2018), providers of environmental goods and services of green industries not only help to enhance greater productivity and innovation with lower costs but also help to lower the environmental impact. The government can also improve the cities by providing facilities that are safe for the environment. Besides, to support and enhance the local economy in order to lessen poverty, the local government has come up with some strategies that can attract and encourage youth enrolment, community empowerment and gender equality in the industry. In term of enabling quality activities for the environment, it is essential for the industry that produces building materials to avoid materials used from damaging human life and environment. As a motivation for environmental growth, the partnership among all relevant players such as businesses, government, academia and civil society must be encouraged by taking up smart new technologies.

With the implementation of SDGs by 2030, the first contribution by the industry is to ensure adequate access for all, provide safe and affordable housing, provide essential services and upgrade slum areas. When this is related to the accessibility for PWDs, there will be more job opportunities for them. As a result, they can afford to buy a house, they will feel safe, and they even can use the essential services that are provided. The second contribution is, to provide access to the secure, affordable, accessible and sustainable transport system for all. One way is to improve road safety by expanding public transport with special consideration to the needs of women, children, disabled people and older persons.

According to Eizenberg and Jabareen (2017), social sustainability still lacks in theories and empirical studies. The concept of equity, safety, eco-prosumption and urban forms suggests the main attributes that should be thought about in social sustainability in general. However, relating to public transportation, a few elements such as accessibility, pedestrian-friendly, social interaction, physical activity and safety are among the factors that are accounted for in the discussion. As mentioned earlier, the physical aspect plays a vital role in providing facilities for PWDs, so that they will feel that they are a part of the community. On the other hand, the non-physical aspects should also be considered in order to achieve social 
sustainability. As proposed by Dempsey, Brown and Bramley (2012), the pride, sense of place attachment and community stability, employment, social cohesion, cultural tradition and community organisation are the components that contribute to social sustainability in any development. These components will be highlighted in further research.

\subsection{Conclusions and Recommendations}

Accessibility for PWDs is inclusive of the well-being and sustainable development where all people have their rights to enjoy life and needs. It is crucial for sustainability to meet the present and future needs of all generations. This will enable all generations to appreciate what the older generation had. The design of all public transport stations needs to provide good accessibility to all people of all ages, abilities and disabilities. All professional key players in the industry must take this issue seriously and provide the necessary accessibility and build the right facilities that are aligned with the Malaysia Standard (MS). In order to achieve a higher level of inclusion of PWDs in the society, the accessibility of public transport is crucial. PWDs also have their rights to work, have a good social life and move freely. SDGs Goal 11 can give benefits to all especially to PWDs for their well-being and sustainable life. Therefore, to make PWDs participate in society, a pleasant and conducive environment is needed. Having a proper infrastructure is also very essential.

The necessary facilities provided at public transport stations must consider all types of affordable people who use them. The accessibility of the facilities must be suitable for all types of people such as children, teenagers, adults, aged people and PWDs. The appointed agencies and designers must realise that the facilities provided can be used practically and are safe to the community. The design of public transport must also be flexible for the convenience of children, aged people and PWD. In conclusion, to ensure social sustainability for PWDs, appropriate infrastructure and accessibility of facilities must be seriously considered when implementing any development. All public transport stations must be safe and friendly for all types of people, and this eventually will attract more people to use public transport services.

\section{Acknowledgement}

This paper is prepared for further study in social sustainability for PWDs. An acknowledgement should be addressed to Universiti Teknologi MARA, Perak Brank for giving support and grant to present this paper.

\section{References}

Bascom, G. (2017). Transportation Related Challenges for Persons' with Disabilities Social Participation. All Graduate Thesis and Dissertations, 5265.

Brundtland Report (1987). Our Common Future. World Commission on Environment and Development (WCED). 
[Online] [Retrieved on 20 April, 2018]. http://www.un-documents.net/wced-ocf.htm.

Dempsey, N., Brown, C. and Bramley G. (2012). The Key to Sustainable Urban Development in UK Cities? The Influence of Density on Social Sustainability. Prog. Plan, 77(3), 89-141.

Department of Social Welfare. (2015). Statistic of Disabled People. [Online] [Retrieved on 20 May, 2018]. Available: http://www.jkm.gov.my/jkm/index.

Eizenberg, E. and Jabareen, Y. (2017). Social Sustainability: A New Conceptual Framework. Sustainability, 9(1), 68-83.

Law of Malaysia (2008). Persons with Disabilities Act, 2008. The government of Malaysia.

Ishak, M. (2017). Perkhidmatan MRT tidak abaikan OKU, Warga Emas. Berita Harian Online [Online] [Retrieved on 24 July 2018]. Available: https://www.bharian.com.my/berita/nasional-2017-08-309742-perkhidmatan-mrt-tidakabaikan-oku-warga-emas.

Ishak, M. S. and MadSah, N. (2016). The Building Suitability and an Existing Facility on Bus Station in Northern Malaysia. Modern Management Science \& Engineering, 4(2), 111-118.

Islam, M. R. (2015). Rights of the People with Disabilities and Social Exclusion in Malaysia. International Journal of Social Science and Humanity, 5(2), 171-177.

Ismail, A. M., Marzuki, M., Daud, M. N. and Borham, A. H. (2015). Provision of Facilities for Persons with Disabilities (PWDs) in the Mosques: A Case Study in Mosques District of Batang Padang. Al-Hikmah, 7(1), 62-78.

Jabareen, Y. (2015). The Risk City: Cities Countering Climate Change: Emerging Planning Theories and Practices around the Worlds; New York: Springer.

Kaur, G., Leong, T. P., Yusof, J. M. and Singh, D. (2015). Perception of People with Disability in Creating Sustainable Public Policy. Social and Behavior Sciences, 168, 145-155.

Mokthsim, N. and Salleh, K. O. (2014). Malaysia's Efforts Toward Achieving a Sustainable Development: Issues, Challenges and Prospects. Social and Behavioural Sciences, 120, 299-307.

Parker, C. J., May, A., Mitchell, V. and Burrows, A. (2013). Capturing Volunteered Information for Inclusive Service Design: Potential Benefits and Challenges. The Design Journal, 16(2), 197-218.

Prasertsubpakij, D. and Nitivattananon, V. (2012). Evaluating Accessibility to Bangkok Metro Systems using Multidimensional Criteria Across User Groups. IATSS Research, 36(1), 56-65.

Rahim, A. A., Zen, I., Samad, N. A. A. and Rahim, C. R. C. (2014). Universal Design and Accessibility: Towards Sustainable Built Environment in Malaysia. Universal Design, 299-306.

Sierra, L.A., Yepes V., and Pellicer, E. (2018). Review of multi-criteria assessment of the social sustainability of infrastructures. Journal of Cleaner Production, 187 (496-513).

Siri, J. \& Capon, A. (2015). Health and Wellbeing in Sustainable Urban Development. International Institute for Global Health. United Nations University, 1-4

Soltani, S. H. K., Sham, M., Awang, M. and Yaman, R. (2012). Accessibility for Disabled in Public Transportation Terminal. Social and Behavior Science, 35, 89-96.

Tan, P. (2008). The Digital Awakening - Prasarana and Its Disabling Assets. [Online] [Retrieved on 24 July 2018]. 
Available: http://www.petertan.com/blog/tag/syarikat-prasarana-negara-berhad/

Solvoll, G., and Hanssen, T.E.S. (2017). User Satisfaction with Specialised Transport for Disabled in Norway. Journal of Transport Geography, 62, 1-7.

UNDP (2018). Sustainable Development Goals. [Online] [Retrieved on 18 May, 2018]. Available:

www.my.undp.org/content/malaysia/en/home/sustainable-development-goals.html.

Vallance, S., Perkins, H. C. and Dixon, J. E. (2011). What Is Social Sustainability? A clarification of concepts. Geoforum, 42(3), 342-348.

WHO Report. (2018). World Report on Disability. [Online] [Retrieved on 20 May, 2018]. Available: http://www.who.int/disabilities/world_report.

Yue, P. H. (2009, January 28). Falling Short. The Star Online [Online] [Retrieved on 24 July 2018]. Available: www.petertan.com/blog/2009/01/

Mehdi K., \& Koorosh, A. (2015). Achievement to Environmental Components of Educational Spaces for Iranian Trainable Children with Intellectual Disability. Procedia - Social and Behavioral Sciences, 201, 9-18

Mettam, G. R., \& Adams, L. B. (1999). How to prepare an electronic version of your article. In B. S. Jones \& R. Z. Smith (Eds.), Introduction to the electronic age (pp. 281-304). New York: E-Publishing In 